AстA Pó́tica 37•2

julio-diciembre

$2016(124-126)$

\title{
Carmen Elena Armijo Canto. Fábula y mundo: Odo de Chériton y el "Libro de los gatos". México: UNAM-IIFL: Centro de Poética, 2014.
}

José Antonio Muciño RuIZ

jamucino@yahoo.com.mx

La publicación del libro Fábula y mundo: Odo de Chériton y el "Libro de los gatos" de Carmen Elena Armijo Canto, profesora e investigadora de la Universidad Nacional Autónoma de México (UNAM), es una importante contribución a los estudios medievales hispánicos realizados en México, cuyo alcance se proyecta a todo el mundo académico interesado en la cultura medieval española, no sólo en la narrativa medieval centrada en los exempla. El exempla fue una forma narrativa ampliamente utilizada por la Iglesia y la Monarquía para promover una visión cristiana del mundo, que constituye una herencia cultural para Occidente. Una herencia que incluye a la literatura que se produjo tanto en la Alta como en la Baja Edad Media, en lengua latina y en lengua romance. Sus valores intrínsecos, estéticos (poé- ticos) y comunicativos, están en estrecha relación con la visión del mundo que construyó el cristianismo a lo largo de varios siglos y que cristalizó en la edificación de las catedrales, en la Suma teológica de Tomás de Aquino y en la Comedia de Dante.

En este sentido, si bien la narrativa medieval puede verse en sí misma como objeto de estudio, es decir, como mera literatura, se debe tener presente que para los hombres medievales muchas de sus narraciones eran obras que adoctrinaban entreteniendo, siguiendo la propuesta horaciana. Su recepción estaba condicionada por una visión del mundo, construida de tal manera que el hombre no podía comprender su realidad física y metafísica fuera de ella. Recordemos que la fractura de este mundo se inicia con el Humanismo (renacentista), hasta ser casi abo- 
lida por la ciencia en el siglo xx, débilmente sostenida por una Iglesia a la baja y una grey cada vez más escéptica en nuestros días.

Fábula y mundo de Carmen Armijo, y éste es uno de sus muchos méritos, nos advierte a los lectores que en la Edad Media la literatura, como signo complejo, no sólo responde a una tradición narrativa oriental y grecolatina, sino que su referente es un contexto histórico-social construido en función de la ideología cristiana. Por eso, como lector, me hubiera gustado que el capítulo V: "La visión del mundo en el Libro de los gatos" fuera más extenso, porque la imagen del mundo se propone como una de las claves de la lectura, tanto para la obra de Odo de Chériton como para la del "traductor" del Libro de los gatos. De esta manera podríamos entender mejor que los diferentes aspectos que se desarrollan en las fábulas de ambas obras (misoginia, bestiario, catarismo, el diablo, etc.) son parte de una concepción medieval más amplia.

Salvo este reparo, que como lector hago al orden y extensión de los capítulos, el libro Fábula y mundo es de una gran riqueza para los lectores interesados en el tema, especialistas y no especialistas; desde la aportación bibliográfica, hasta el contenido de cada capítulo que no es sólo un conocimiento particular de la obra de Odo de Chériton y del Libro de los gatos, tanto lingüístico como histórico literario, sino cultural en general. Por ejemplo, en el capítulo III, titulado " $E l$ Libro de los gatos", la autora nos da un excelente panorama sobre la historia del libro en la Edad Media, que resulta un plus para el lector, que amplía sus conocimientos sobre la cultura medieval; lo mismo podría decirse de todos los capítulos que conforman la obra.

Fabula y mundo también puede leerse como una introducción a la narrativa medieval, como un panorama del pensamiento medieval y como la trayectoria intelectual de la autora y su relación con el mundo medieval. Este libro nos invita a un viaje por una época que como todas las épocas está llena de luces y sombras; por lo tanto hay que agradecer a Carmen Armijo la posibilidad de hacer este viaje en donde encontraremos aspectos que creíamos conocidos, vistos bajo una nueva luz, y otros novedosos que contribuirán a hacernos una idea más precisa de lo que fue la Edad Media.

Sólo nos queda esperar una edición más accesible de divulgación del Libro de los gatos de Carmen Armijo, que ha hecho de la obra uno de sus libros de cabecera, donde aspectos filológicos tanto de la obra de Odo de Chériton como de su traducción en el Libro de los gatos que no fueron contemplados, puedan ser desarrollados para gusto de los lectores. Así que no sólo felicitamos a la autora sino a nosotros como lectores que disponemos de un texto que es como una pequeña suma literaria que nos guiará por la visión del mundo medieval. 
JosÉ Antonio MuciÑo RuIZ

Licenciado en Lengua y Literaturas Hispánicas y en Filosofía por parte de la Facultad de Filosofía y Letras de la UnAM. Maestro en Lenguas Españolas en la Facultad de Filosofía y Letras de la UNAM. Doctor en Literatura Hispánica por parte del Colegio de México. Profesor de Carrera de Tiempo Completo del Colegio de Letras Hispánicas.

Literatura Española Medieval, Literatura Española de los Siglos de Oro y Seminarios de Teoría Literaria y Crítica Literaria. Actualmente trabaja en una investigación sobre la Hermenéutica de la poesía barroca española. 